\title{
Dose-dependent effects of vitamin D on transdifferentiation of skeletal muscle cells to adipose cells
}

\author{
Kevin J P Ryan, Zoe C T R Daniel, Lucinda J L Craggs, Tim Parr and John M Brameld \\ Division of Nutritional Sciences, School of Biosciences, University of Nottingham, Loughborough, Leics LE12 5RD, UK
}

Correspondence should be addressed to J M Brameld Email

john.brameld@nottingham.ac.uk

\begin{abstract}
Fat infiltration within muscle is one of a number of features of vitamin D deficiency, which leads to a decline in muscle functionality. The origin of this fat is unclear, but one possibility is that it forms from myogenic precursor cells present in the muscle, which transdifferentiate into mature adipocytes. The current study examined the effect of the active form of vitamin $D_{3}, 1,25$-dihydroxyvitamin $D_{3}\left(1,25(\mathrm{OH})_{2} D_{3}\right)$, on the capacity of the $C 2 C 12$ muscle cell line to differentiate towards the myogenic and adipogenic lineages. Cells were cultured in myogenic or adipogenic differentiation media containing increasing concentrations $\left(0,10^{-13}, 10^{-11}, 10^{-9}, 10^{-7}\right.$ or $\left.10^{-5} \mathrm{M}\right)$ of $1,25(\mathrm{OH})_{2} \mathrm{D}_{3}$ for up to 6 days and markers of muscle and fat development were measured. Mature myofibres were formed in both adipogenic and myogenic media, but fat droplets were only observed in adipogenic media. Relative to controls, low physiological concentrations $\left(10^{-13}\right.$ and $\left.10^{-11} \mathrm{M}\right)$ of $1,25(\mathrm{OH})_{2} \mathrm{D}_{3}$ increased fat droplet accumulation, whereas high physiological $\left(10^{-9} \mathrm{M}\right)$ and supraphysiological concentrations $\left(\geq 10^{-7} \mathrm{M}\right.$ ) inhibited fat accumulation. This increased accumulation of fat with low physiological concentrations $\left(10^{-13}\right.$ and $\left.10^{-11} \mathrm{M}\right)$ was associated with a sequential up-regulation of Ppary2 (Pparg) and Fabp4 mRNA, indicating formation of adipocytes, whereas higher concentrations $\left(\geq 10^{-9} \mathrm{M}\right)$ reduced all these effects, and the highest concentration $\left(10^{-5} \mathrm{M}\right)$ appeared to have toxic effects. This is the first study to demonstrate dose-dependent effects of $1,25(\mathrm{OH})_{2} \mathrm{D}_{3}$ on the transdifferentiation of muscle cells into adipose cells. Low physiological concentrations (possibly mimicking a deficient state) induced adipogenesis, whereas higher (physiological and supraphysiological) concentrations attenuated this effect.
\end{abstract}

Journal of Endocrinology

(2013) 217, 45-58

\section{Introduction}

Vitamin D (VitD) is a key nutrient for maintaining the health of the musculoskeletal system, with VitD deficiency leading to myopathy, classically characterised by hypotonia, weakness and atrophy of skeletal muscle, and a deterioration in physical capacity (Ceglia 2008). Muscle biopsies from VitD-deficient adults demonstrate enlarged interfibrillar spaces, fibrosis and loss of type II fibre complement (Yoshikawa et al. 1979, Ceglia 2008). There is also an increase in fat infiltration within the muscle (Ceglia 2008, Oh et al. 2009, Tagliafico et al. 2010) and a similar effect is observed in elderly individuals where the progressive loss in muscle mass and strength seen at the 
onset of sarcopenia is associated with an increase in fat deposition within the tissue (Ryall et al. 2008).

It is of major concern that VitD deficiency is particularly prevalent amongst the elderly population, as its effects on the musculoskeletal system compound the degenerative effects of sarcopenia (Holick 2007). This can have major consequences for their welfare, as the resultant decline in basic muscle function leads to an increased risk of falls and bone fractures. This deterioration in muscle strength and functionality is thought to result from not just the loss in muscle fibres but also a progressive infiltration of fat within the tissue (Goodpaster et al. 2001, Ryall et al. 2008). This fat infiltration has been shown to directly impact on muscle strength and functionality and is a key independent risk factor for metabolic diseases such as insulin resistance and diabetes (Goodpaster et al. 2003, Zoico et al. 2010).

In the blood circulation, VitD is found in two main forms - calcidiol or 25-hydroxyvitamin D $(25(\mathrm{OH}) \mathrm{D})$, which is an inactive precursor form, and calcitriol or 1,25-dihydroxyvitamin $\mathrm{D}\left(1,25(\mathrm{OH})_{2} \mathrm{D}\right)$, which is the active form. Blood concentrations of calcidiol range between 30 and $50 \mathrm{nM}$ (i.e. $3-5 \times 10^{-8} \mathrm{M}$; McLeod \& Cooke 1989), whereas calcitriol is much lower, ranging between $\sim 2$ and $350 \mathrm{pM}$ (i.e. $2 \times 10^{-12}-3.5 \times 10^{-10} \mathrm{M}$; Zittermann et al. 2009). The active form, calcitriol, is formed when circulating 25(OH)D is hydroxylated by the $1 \alpha$-hydroxylase enzyme (CYP27b1), present mainly in the kidney, to form the active $1,25(\mathrm{OH})_{2} \mathrm{D}$ (Takeyama \& Kato 2011). Activation then enables $1,25(\mathrm{OH})_{2} \mathrm{D}_{3}$ to bind to the VitD receptor (VDR), a type of nuclear receptor, and thereby regulates transcription of a number of VitD target genes, which is thought to be the principal mechanism of action of VitD. Down-regulation of this response occurs via activation of the 24-hydroxylase enzyme (CYP24a1), which hydroxylates various forms of VitD at carbon 24 resulting in inactivation and targeting for excretion (Holick 2007). De novo synthesis of components required for calcium cycling, phospholipid metabolism and cell proliferation/differentiation in muscle is thought to be mediated by VDR-driven mechanisms operating at the level of gene transcription (Drittanti et al. 1989, Ceglia 2008), thereby playing an important role in maintaining muscle structure and functionality.

The effects of VitD deficiency are reversible, and studies have shown that VitD supplementation increases the relative number and size of type II fibres in aged skeletal muscle, which can improve balance, increase overall muscle strength and ultimately reduce the incidence of falls (Bischoff et al. 2003, Harwood et al. 2004,
Sato et al. 2005, Moreira-Pfrimer et al. 2009). However, it is not known what effect VitD supplementation has on fat infiltration within muscle. Indeed, the origin of these adipose cells and the mechanism by which they mature within muscle remains unclear. It may correspond to aberrant transdifferentiation of myogenic precursor cells into adipocytes resulting in the formation of fat within the intermuscular space (Vettor et al. 2009). Certainly numerous studies have demonstrated that myogenic precursor cells retain the potential to transdifferentiate towards the adipogenic lineage (Hu et al. 1995, Grimaldi et al. 1997, Holst et al. 2003, Seale et al. 2008, Vettor et al. 2009). Previous work has shown that VitD has potent effects on both adipogenesis (Ishida et al. 1988, Sato \& Hiragun 1988, Lenoir et al. 1996, Blumberg et al. 2006, Kong \& Li 2006, Thomson et al. 2007, Zhuang et al. 2007) and myogenesis (Capiati et al. 1999, Garcia et al. 2011). Most have used physiologically relevant concentrations of $1,25(\mathrm{OH})_{2} \mathrm{D}_{3}$, but some have tended to use high physiological or supraphysiological concentrations. Importantly, it is not known whether VitD affects the transdifferentiation of myogenic precursor cells into adipocytes. In order to address this question, the current study investigated the effect of a broad range of concentrations of the active form of $\operatorname{VitD}_{3}\left(1,25(\mathrm{OH})_{2} \mathrm{D}_{3}\right)$ on the capacity of the murine C2C12 muscle cell line to differentiate or transdifferentiate towards the myogenic or adipogenic lineages respectively. We included $1,25(\mathrm{OH})_{2} \mathrm{D}_{3}$ concentrations covering the physiological range $\left(10^{-13}-10^{-9} \mathrm{M}\right)$, as well as the supraphysiological concentrations $\left(10^{-7}\right.$ and $\left.10^{-5} \mathrm{M}\right)$ used previously in other cell culture studies (Blumberg et al. 2006, Zhuang et al. 2007, Garcia et al. 2011).

\section{Materials and methods}

\section{Cell culture and reagents}

C2C12 cells were cultured in six-well plates in growth media consisting of DMEM (Sigma) supplemented with $10 \%$ heat-inactivated fetal bovine serum (hi-FBS), 100 units $/ \mathrm{ml}$ penicillin and $0.1 \mathrm{mg} / \mathrm{ml}$ streptomycin and maintained at $37{ }^{\circ} \mathrm{C}$ under $5 \% \quad \mathrm{CO}_{2}$ until $70-80 \%$ confluent. This corresponded to day 0 of differentiation, at which stage cells were switched to either myogenic or adipogenic differentiation media and incubated for up to 6 days at $37^{\circ} \mathrm{C}$ under $5 \% \mathrm{CO}_{2}$. Myogenic differentiation media consisted of DMEM containing $2 \%$ horse serum and antibiotics and was changed every 2 days until the end of the experiment. For induction of adipogenic differentiation, cells were

Published by Bioscientifica Ltd. 
cultured in DMEM containing 10\% hi-FBS, antibiotics, $0.5 \mathrm{mM}$ isobutylmethylxanthine, $1 \mu \mathrm{M}$ dexamethasone, $850 \mathrm{nM}$ insulin, $10 \mathrm{nM}$ tri-iodothyronine $\left(\mathrm{T}_{3}\right)$ and $1 \mu \mathrm{M}$ rosiglitazone (peroxisome proliferator activated receptor $\gamma$ (PPAR $\gamma$ ) agonist) from days 0 to 2 . This induction medium was then replaced with DMEM containing 10\% hi-FBS, antibiotics, $850 \mathrm{nM}$ insulin, $10 \mathrm{nM} \mathrm{T} \mathrm{T}_{3}$ and $1 \mu \mathrm{M}$ rosiglitazone from day 2 onwards and changed every 2 days until the end of the experiment. Both myogenic and adipogenic differentiation media were supplemented with increasing concentrations $\left(0,10^{-13}, 10^{-11}, 10^{-9}, 10^{-7}\right.$ or $\left.10^{-5} \mathrm{M}\right)$ of $1,25(\mathrm{OH})_{2} \mathrm{D}_{3}$ (Sigma), which was dissolved and diluted in DMSO. All treatments (including control) contained $0.1 \%(\mathrm{v} / \mathrm{v})$ DMSO.

\section{Oil Red-O and haematoxylin staining}

Accumulation of lipid droplets was monitored by phase contrast microscopy. After 6 days of exposure to myogenic or adipogenic differentiation media, cells were stained with Oil Red-O to identify lipid droplets and counterstained with haematoxylin to delineate nuclear and myofibre structures. Briefly, media were removed and cells were fixed in $3.7 \%$ formaldehyde at room temperature for $30 \mathrm{~min}$. Cells were washed twice with pre-warmed (to $37^{\circ} \mathrm{C}$ ) $\mathrm{PBS}$ and then with $60 \%$ isopropanol, before staining with $0.3 \%$ Oil Red-O (Sigma) for $30 \mathrm{~min}$ at room temperature. Cells were then washed once in $60 \%$ isopropanol and twice in tap water, before counterstaining with Harris haematoxylin (Sigma) for 3 min, all at room temperature. Excess stain was removed by washing twice in distilled water and then another two times in Scott's tap water $(0.24 \mathrm{M}$ sodium bicarbonate and $0.03 \mathrm{M}$ magnesium sulphate). Images were captured using an Olympus SZH10 microscope (Olympus, Southend-on-Sea, UK) and analysed using Image Pro (version 5.1, Rockville, MD, USA) for the quantification of Oil Red-O staining. The Image Pro Software detected the Oil Red-O staining using a fixed threshold and then calculated percentage area of staining for each image. Five field of view images from each of four replicate wells (i.e. 20 in total) were quantified for each treatment.

\section{Quantitative real-time PCR analysis}

At the required timepoints (days 0, 2, 4 and 6), total RNA was extracted from $\mathrm{C} 2 \mathrm{C} 12$ cells using a High Pure RNA isolation kit (Roche), according to the manufacturer's protocol. Samples were then stored frozen $\left(-80^{\circ} \mathrm{C}\right)$ before first-strand cDNA synthesis using random hexamer primers, as described previously (Hemmings et al. 2009). Quantitative PCR was performed in duplicate using SYBR1 Master mix (Roche), 384-well microplates and the LightCycler LC480 (Roche) configured for SYBR green detection, again as described previously (Tonge et al. 2010). The primers for each transcript were designed using Primer Express (Applied Biosystems) and are shown in Table 1. A standard curve was produced using serial dilutions of a pool of cDNA made from all samples to check the linearity and efficiency of the PCR for every gene, while melt curve analysis was used to check whether there was only a single product. Transcript abundance was determined using the standard curve method as described previously (Brown et al. 2012). Previous studies in this cell line (Brown et al. 2012) had demonstrated that expression of all the common 'housekeeper' genes changes during differentiation; therefore, all data were normalised to total first-strand cDNA content, measured using Oligreen, as described previously (Brown et al. 2012).

\section{Creatine kinase, DNA and protein assays}

At the required timepoint (day 4), C2C12 cells from each well were scraped into $1 \mathrm{ml}$ of cold $\left(4^{\circ} \mathrm{C}\right)$ tri-sodium citrate buffer (0.05 M, pH 6.8) and sonicated on ice for $15 \mathrm{~s}$ using a benchtop ultrasonicator (Soniprep 150; MSE, London, (UK) Ltd.), being stored frozen $\left(-80^{\circ} \mathrm{C}\right)$ before analysis. Creatine kinase (CK) activity (IU/well) was measured using a CK assay kit (Thermo Scientific Cramlington, Northumberland, UK), as described previously (Brown et al. 2012). Briefly, thawed samples were transferred on to a 96-well microtitre plate and $200 \mu \mathrm{l}$ of reaction buffer was added according to the manufacturer's instructions. Absorption at $340 \mathrm{~nm}$ was measured at $30^{\circ} \mathrm{C}$ every $5 \mathrm{~min}$ over a 30 -min period. DNA content ( $\mu \mathrm{g} /$ well) of the thawed cell lysate was measured using a fluorescence plate reader assay adapted from Rago et al. (Rago et al. 1990, Hurley et al. 2006). Protein content ( $\mu$ g/well) was measured via the Lowry method (Lowry et al. 1951) adapted for 96-well plate format. Usually, we normalise the CK activity data to DNA content to account for differences in numbers of cells in each well. However, in this case, normalising the CK activity data to DNA resulted in the differences in CK activity observed between media types (myogenic vs adipogenic) being exaggerated due to the obvious differences in DNA contents (i.e. numbers of cells and their differing morphology), as there were clear differences in the types of cells present. We therefore opted to include the three measurements (CK activity, protein and DNA) separately on a per well basis.

Published by Bioscientifica Ltd. 
Table 1 Mouse-specific Primer sequences used for quantitative real-time PCR analysis. Primer sequences for PPAR $\gamma 1$, PPAR $\gamma 2$ and UCP1 were obtained from Kajimura et al. (2009)

\begin{tabular}{|c|c|}
\hline Gene & Primer sequence $\left(5^{\prime}-3^{\prime}\right)$ \\
\hline \multirow[t]{2}{*}{ MyoD } & Forward: CGTGGCAGCGAGCACTAC \\
\hline & Reverse: TGTAATCCATCATGCCATCAGA \\
\hline \multirow[t]{2}{*}{ Creatine kinase } & Forward: GCACTGGCCGCAGCAT \\
\hline & Reverse: GAGGGTAGTACTTGCCCTTGAACTC \\
\hline \multirow[t]{2}{*}{ Myogenin } & Forward: CCCATGGTGCCCAGTGAA \\
\hline & Reverse: GCAGATTGTGGGCGTCTGTA \\
\hline \multirow[t]{2}{*}{ Myf5 } & Forward: CAGCCCCACCTCCAACTG \\
\hline & Reverse: GCAGCACATGCATTTGATACATC \\
\hline \multirow[t]{2}{*}{ Ppary1 } & Forward: TGAAAGAAGCGGTGAACCACTG \\
\hline & Reverse: TGGCATCTCTGTGTCAACCATG \\
\hline \multirow[t]{2}{*}{ Ppary2 } & Forward: GCATGGTGCCTTCGCTGA \\
\hline & Reverse: TGGCATCTCTGTGTCAACCATG \\
\hline \multirow[t]{2}{*}{ Fabp4 } & Forward: AAGTGGGAGTGGGCTTTGC \\
\hline & Reverse: TGGTGACCAAATCCCCATTT \\
\hline \multirow[t]{2}{*}{ AdipoQ } & Forward: GACACCAAAAGGGCTCAGGAT \\
\hline & Reverse: TGGGCAGGATTAAGAGGAACA \\
\hline \multirow[t]{2}{*}{ Leptin } & Forward: CAAGCAGTGCCTATCCAGAAAGT \\
\hline & Reverse: CAAGCAGTGCCTATCCAGAAAGT \\
\hline \multirow[t]{2}{*}{ Ucp1 } & Forward: ACTGCCACACCTCCAGTCATT \\
\hline & Reverse: CTTTGCCTCACTCAGGATTGG \\
\hline \multirow[t]{2}{*}{ Prdm16 } & Forward: GAAGGTGTCCAAACTGACAATGC \\
\hline & Reverse: CGTCACTTTTGGCTAGCTTCCT \\
\hline \multirow[t]{2}{*}{ Elovl3 } & Forward: ATGAATTTCTCACGCGGGTTA \\
\hline & Reverse: GCTTACCCAGTACTCCTCCAAAAA \\
\hline \multirow{2}{*}{ Cidea } & Forward: CCAGAGTCACCTTCGACCTATACA \\
\hline & Reverse: CTCGTACATCGTGGCTTTGACA \\
\hline \multirow[t]{2}{*}{$C / e b p \beta$} & Forward: AGCGGCTGCAGAAGAAGGT \\
\hline & Reverse: GGCAGCTGCTTGAACAAGTTC \\
\hline \multirow[t]{2}{*}{$\operatorname{Pgc1} \alpha$} & Forward: TGCAGCGGTCTTAGCACTCA \\
\hline & Reverse: CATGAATTCTCGGTCTTAACAATGG \\
\hline
\end{tabular}

\section{Statistical analysis}

Data were analysed by one- or two-way ANOVA for effects of $1,25(\mathrm{OH})_{2} \mathrm{D}_{3}$ concentration, media type (myogenic or adipogenic) and/or timepoint (as appropriate) using SPSS Statistical Software (19th Edition, Portsmouth, Hampshire, UK). Percentage area of Oil Red-O staining was analysed by one-way ANOVA $\left(1,25(\mathrm{OH})_{2} \mathrm{D}_{3}\right.$ concentration only). CK activities, DNA and protein contents were analysed by two-way ANOVA $\left(1,25(\mathrm{OH})_{2} \mathrm{D}_{3}\right.$ concentration and media type). All real-time qPCR data were analysed by two-way ANOVA $\left(1,25(\mathrm{OH})_{2} \mathrm{D}_{3}\right.$ concentration and timepoint), with the data from myogenic and adipogenic media being analysed separately. A post-hoc Bonferroni's test was used when appropriate (i.e. no significant interactions). All means are for either $n=3$ (CK activity, protein and DNA contents) or $n=4$ (Oil Red-O staining and all mRNA expression) replicates (i.e. wells) for each treatment and media type at each timepoint. $P<0.05$ was considered statistically significant.

\section{Results}

\section{Effects of $1,25(\mathrm{OH})_{2} \mathrm{D}_{3}$ on myotube formation and lipid accumulation}

Myotube formation was clearly evident in control cells after 6 days in either myogenic or adipogenic differentiation media (Fig. 1A and G). Phase contrast images of control cells showed extensive myotube formation by day 4 in myogenic media, which did not appear to increase any further on day 5 (data not shown). By contrast, myotubes were still visibly forming throughout days 4 and 5 of differentiation in control cells in adipogenic media (data not shown), suggesting that myogenic differentiation was slightly delayed, but there appeared to be no difference in myotube formation between myogenic and adipogenic media on day 6 (Fig. 1A and G).

Positive Oil Red-O staining confirmed the presence of lipid droplets in control cells grown for 6 days in adipogenic media (Fig. 1G), but there was no Oil Red-O staining of cells grown in myogenic media (either without or with $1,25(\mathrm{OH})_{2} \mathrm{D}_{3}$ ) for the same length of time (Fig. 1A, B, C, D, E and F). Similarly, phase contrast images taken at earlier timepoints demonstrated the formation of lipid droplets after 4 days, but only in cells cultured in adipogenic media (data not shown).

Dose-dependent effects of $1,25(\mathrm{OH})_{2} \mathrm{D}_{3}$ supplementation for 6 days were observed on myotube formation, with addition of supraphysiological concentrations $\left(10^{-7}\right.$ and $\left.10^{-5} \mathrm{M}\right)$ appearing to inhibit myotube formation in both myogenic and adipogenic media (Fig. 1E, F, K and L). Relative to the control cells grown for 6 days in adipogenic media, supplementation with increasing concentrations of $1,25(\mathrm{OH})_{2} \mathrm{D}_{3}$ induced a bimodal effect on lipid droplet accumulation in cells cultured in adipogenic media, as determined by percentage area of Oil Red-O staining (Fig. 2). At the lowest physiological concentration $\left(10^{-13} \mathrm{M}\right), 1,25(\mathrm{OH})_{2} \mathrm{D}_{3}$ significantly increased lipid droplet accumulation compared with controls $(P<0.01$ Bonferroni; Figs $1 \mathrm{H}$ and 2$)$, whereas the highest concentrations $\left(10^{-9} \mathrm{M}\right.$ and above), corresponding to high physiological and supraphysiological concentrations, inhibited lipid droplet formation $(P<0.001$ Bonferroni; Figs 1J, K, L and 2).

\section{Expression of gene markers of white adipocytes}

As observed for lipid droplet formation (Fig. 1G, H, I, J, K and L), C2C12 cells grown in adipogenic media demonstrated induction of genes indicative of differentiation of

Published by Bioscientifica Ltd 
A

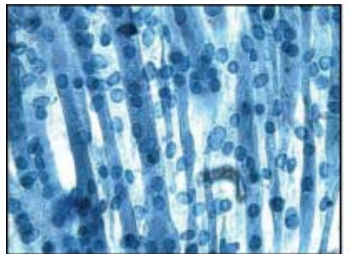

B

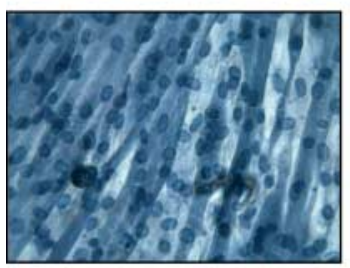

C

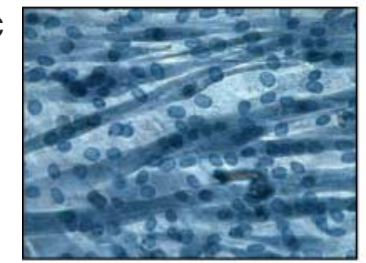

D

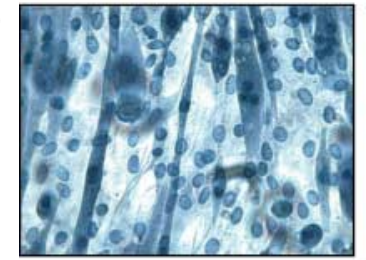

E

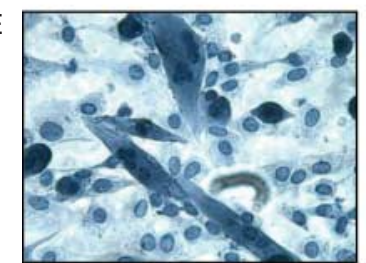

$\mathrm{F}$

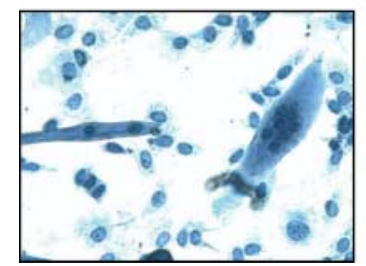

G

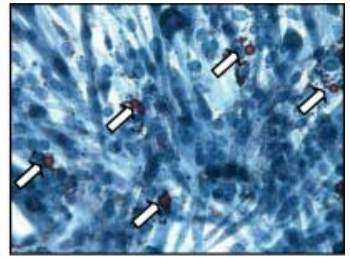

$\mathrm{H}$
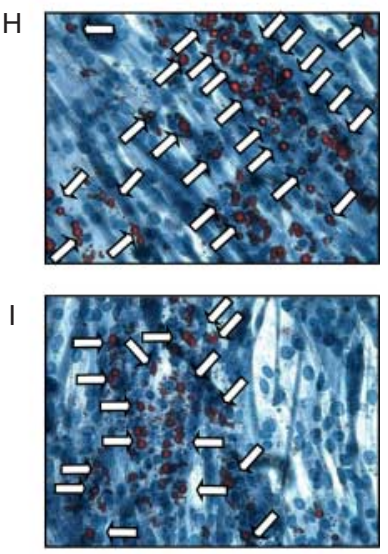

$\mathrm{J}$

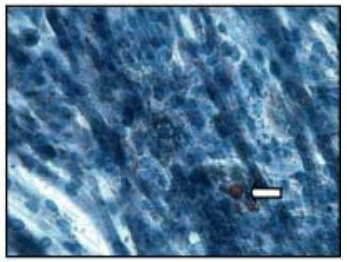

K

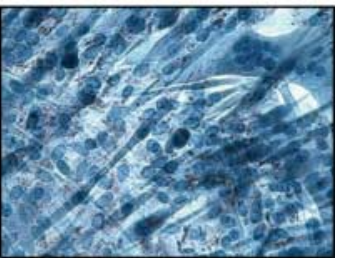

L

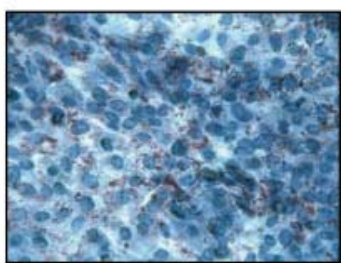

Figure 1

Dose-dependent effects of $1,25(\mathrm{OH})_{2} \mathrm{D}_{3}$ on accumulation of lipid droplets in $C 2 C 12$ cells cultured in myogenic ( $A, B, C, D, E$ and $F)$ or adipogenic $(G, H$, $\mathrm{I}, \mathrm{J}, \mathrm{K}$ and $\mathrm{L}$ ) media. Representative images of $\mathrm{C} 2 \mathrm{C} 12$ cells stained with Oil Red-O (as indicated by white arrows) and counterstained with haematoxylin to indicate lipid droplet and nuclei/myofibre structures respectively. Cells were cultured for 6 days in myogenic ( $A, B, C, D, E$ and $F$ ) or adipogenic $(\mathrm{G}, \mathrm{H}, \mathrm{I}, \mathrm{J}, \mathrm{K}$ and $\mathrm{L}$ ) media with vehicle $(\mathrm{A}$ and $\mathrm{G})$ or increasing concentrations of $1,25(\mathrm{OH})_{2} \mathrm{D}_{3}\left(10^{-13} \mathrm{M}(\mathrm{B}\right.$ and $\mathrm{H}), 10^{-11} \mathrm{M}(\mathrm{C}$ and $\mathrm{I})$, $10^{-9} \mathrm{M}(\mathrm{D}$ and $\mathrm{J}), 10^{-7} \mathrm{M}(\mathrm{E}$ and $\mathrm{K})$ or $10^{-5} \mathrm{M}(\mathrm{F}$ and $\left.\mathrm{L})\right)$.

white adipocytes (Fig. 3A, B and C). For clarity, we only include figures for the expression of genes in adipogenic media, but the figures showing expression of these same genes by cells cultured in myogenic media are included in the Supplementary Figure 1A, B, C and D, see section on supplementary data given at the end of this article. In adipogenic media, expression of all three adipose-specific marker genes, Ppary2 (Pparg; Fig. 3A), fatty acid binding protein 4 (Fabp4; Fig. 3B) and adiponectin/Adipoq (Fig. 3C), were induced in a $1,25(\mathrm{OH})_{2} \mathrm{D}_{3}$ concentration and time-dependent manner $(P<0.001$ for all three $1,25(\mathrm{OH})_{2} \mathrm{D}_{3}$ concentration $\times$ day interactions), but only in cells grown in adipogenic media. Low physiological concentrations $\left(10^{-13}\right.$ and $\left.10^{-11} \mathrm{M}\right)$ of $1,25(\mathrm{OH})_{2} \mathrm{D}_{3}$ increased expression of all three genes, with levels of PPAR 2 peaking at day 2 and declining over days 4 and 6 (Fig. 3A), while expression of the PPAR $\gamma 2$ target genes, Fabp 4 and Adipoq, peaked 2 days later at day 4 of differentiation (Fig. 3B and C). Interestingly, the high physiological $\left(10^{-9} \mathrm{M}\right)$ and supraphysiological $\left(10^{-7}\right.$ and $\left.10^{-5} \mathrm{M}\right)$ concentrations of $1,25(\mathrm{OH})_{2} \mathrm{D}_{3}$ decreased expression of all three genes, corresponding to the observed decrease in lipid droplet formation. By contrast, expression of these genes by cells incubated in myogenic media was either undetectable (PPAR $\gamma 2$; Supplementary Figure $1 \mathrm{~A}$ ) or only expressed in the presence of supraphysiological concentrations of $1,25(\mathrm{OH})_{2} \mathrm{D}_{3}$ (FABP4 and ADIPOQ; Supplementary Figure $1 \mathrm{~B}$ and C). Leptin mRNA was not detectable in any of the cultures (in adipogenic or myogenic media) throughout the 6-day period (data not shown). In contrast to PPAR $\gamma 2$, which is known to be adipocyte specific, Ppary 1 mRNA was detected in all cultures (in both myogenic and adipogenic media) and was found to be higher at day 2 than at day $6(P=0.002$ for day effect; Fig. 3D) in adipogenic media and higher in controls and $10^{-5} \mathrm{M} 1,25(\mathrm{OH})_{2} \mathrm{D}_{3}$ than the other concentrations $\left(P=0.005\right.$ for $1,25(\mathrm{OH})_{2} \mathrm{D}_{3}$ concentration effect; Fig. 3D) again in adipogenic media.

\section{Effects of $1,25(\mathrm{OH})_{2} \mathrm{D}_{3}$ on myogenic differentiation in myogenic and adipogenic media}

It was apparent from the morphological studies that supplementation with supraphysiological concentrations $\left(10^{-7}\right.$ and $\left.10^{-5} \mathrm{M}\right)$ of $1,25(\mathrm{OH})_{2} \mathrm{D}_{3}$ inhibited myotube formation in both myogenic and adipogenic media (Fig. 1E, F, K and L). We therefore determined CK activities after 4 days of treatment, as a quantitative measure of myogenic differentiation. Lower CK activities were observed for control cells in adipogenic compared with

Published by Bioscientifica Ltd. 


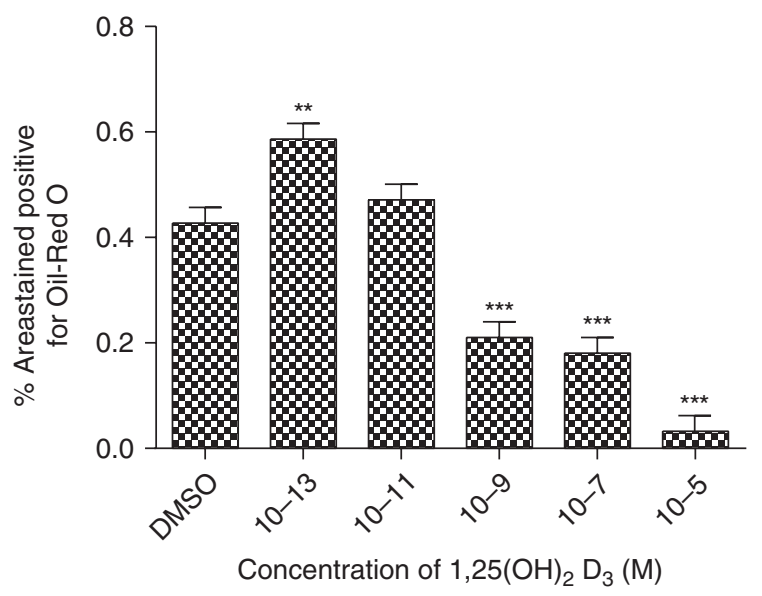

Figure 2

Dose-dependent effects of $1,25(\mathrm{OH})_{2} \mathrm{D}_{3}$ on percentage area of lipid accumulation in $\mathrm{C} 2 \mathrm{C} 12$ cells cultured in adipogenic media for 6 days. $\mathrm{C} 2 \mathrm{C} 12$ cells were stained with Oil Red-O and counterstained with haematoxylin, before the percentage area of the red stain within a field of view (FOV) was quantified by image analysis to give a representative percentage area per well ( $n=4$ wells, five FOV/well). One-way ANOVA indicated a significant effect of $1,25(\mathrm{OH})_{2} \mathrm{D}_{3}(P<0.001)$. Significant differences compared to DMSO control cells were determined by post-hoc Bonferroni's test $(* * P<0.01$ and $* * * P<0.001)$.

myogenic media (Fig. 4A), but supplementation of the adipogenic media with $1,25(\mathrm{OH})_{2} \mathrm{D}_{3}$ increased CK activity to levels approaching those observed in control cells in myogenic media and the magnitude of this increase was similar between $10^{-13}$ and $10^{-7} \mathrm{M}(P<0.001$ for media $\times 1,25(\mathrm{OH})_{2} \mathrm{D}_{3}$ concentration interaction; Fig. $\left.4 \mathrm{~A}\right)$. By contrast, cells exposed to $10^{-5} \mathrm{M} 1,25(\mathrm{OH})_{2} \mathrm{D}_{3}$ in adipogenic media showed a decrease in CK activity compared with controls $\left(P<0.001\right.$ for media $\times 1,25(\mathrm{OH})_{2} \mathrm{D}_{3}$ concentration interaction; Fig. 4A), indicating an attenuation of myogenic differentiation, consistent with the observed absence of myotubes in these cultures (Fig. 1L). In myogenic media, addition of $1,25(\mathrm{OH})_{2} \mathrm{D}_{3}$ at $10^{-7}$ and $10^{-5} \mathrm{M}$ was also associated with a reduction in CK activity $\left(P<0.001\right.$ for media $\times 1,25(\mathrm{OH})_{2} \mathrm{D}_{3}$ concentration interaction; Fig. 4A), as well as reductions in total protein $\left(P<0.01\right.$ for media $\times 1,25(\mathrm{OH})_{2} \mathrm{D}_{3}$ concentration interaction; Fig. 4B) and total DNA $(P<0.001$ for media $\times$ $1,25(\mathrm{OH})_{2} \mathrm{D}_{3}$ concentration interaction; Fig. $\left.4 \mathrm{C}\right)$ contents at day 4. Protein (Fig. 4B) and DNA (Fig. 4C) contents were greater in cells cultured in adipogenic compared with myogenic media, indicative of increased cell proliferation, probably due to the higher FBS content of the adipogenic media. Similar to effects in myogenic media, increasing $1,25(\mathrm{OH})_{2} \mathrm{D}_{3}$ concentrations in adipogenic media decreased both protein $(P<0.01$ for media $\times$ $1,25(\mathrm{OH})_{2} \mathrm{D}_{3}$ concentration interaction; Fig. $\left.4 \mathrm{~B}\right)$ and DNA $\left(P<0.001\right.$ for media $\times 1,25(\mathrm{OH})_{2} \mathrm{D}_{3}$ concentration interaction; Fig. 4C) contents in a dose-dependent manner, but particularly at the highest (supraphysiological) concentrations.

\section{Expression of myogenic marker genes}

Consistent with myotube formation being observed in both types of differentiation media (Fig. 1A, B, C, D, E, F, G and $\mathrm{H})$, muscle-specific genes were expressed in cells grown in either myogenic or adipogenic media. For clarity, we will mainly describe the results from studies using adipogenic media here, but figures for expression of the same genes by cells cultured in myogenic media are included in the Supplementary Figure 1E, F, G and H. The effects of $1,25(\mathrm{OH})_{2} \mathrm{D}_{3}$ (particularly physiological concentrations) on myogenic marker genes were more pronounced in adipogenic media (Fig. 5A, B, C and D) compared with myogenic media (Supplementary Figure 1E, F, G and $\mathrm{H}$ ), consistent with the results obtained for CK activity. Similar to CK activity, CK mRNA expression was lower in adipogenic media compared with myogenic media (Fig. 5A and Supplementary Figure 1E). An increase in CK mRNA was observed at day 4 in control cells (in adipogenic media), but supplementation of adipogenic media with physiological concentrations $\left(10^{-13}, 10^{-11}\right.$ and $\left.10^{-9} \mathrm{M}\right)$ of $1,25(\mathrm{OH})_{2} \mathrm{D}_{3}$ increased $\mathrm{CK}$ mRNA expression particularly on day 4 , whereas $10^{-5} \mathrm{M}$ $1,25(\mathrm{OH})_{2} \mathrm{D}_{3}$ blocked/inhibited differentiation at all timepoints $\left(P<0.001\right.$ for $1,25(\mathrm{OH})_{2} \mathrm{D}_{3}$ concentration $\times$ day interaction; Fig. 5A). A similar pattern was observed for myogenin expression (Fig. 5B). Adipogenic media induced a smaller increase in myogenin mRNA on day 2 compared with myogenic media (Fig. 5B and Supplementary Figure 1F), but myogenin mRNA continued to increase on days 4 and 6 in adipogenic media and actually exceeded the levels observed in myogenic media (Fig. 5B and Supplementary Figure 1F). Supplementation of adipogenic media with $10^{-13}, 10^{-11}, 10^{-9}$ or $10^{-7} \mathrm{M} 1,25(\mathrm{OH})_{2} \mathrm{D}_{3}$ increased myogenin mRNA, particularly on day 2 , whereas $10^{-5} \mathrm{M}$ $1,25(\mathrm{OH})_{2} \mathrm{D}_{3}$ blocked differentiation at all timepoints $\left(P<0.001\right.$ for $1,25(\mathrm{OH})_{2} \mathrm{D}_{3}$ concentration $\times$ day interaction; Fig. 5B). In adipogenic media, there was no change in Myod1 (MyoD) expression in control cells throughout the 6 days of differentiation (Fig. 5C), but supplementation with $10^{-13}, 10^{-11}, 10^{-9}$ or $10^{-7} \mathrm{M}$ $1,25(\mathrm{OH})_{2} \mathrm{D}_{3}$ increased $M y o D$ on days 2 and 4, whereas $10^{-5} \mathrm{M} 1,25(\mathrm{OH})_{2} \mathrm{D}_{3}$ blocked these effects $(P=0.001$ for

Published by Bioscientifica Ltd 

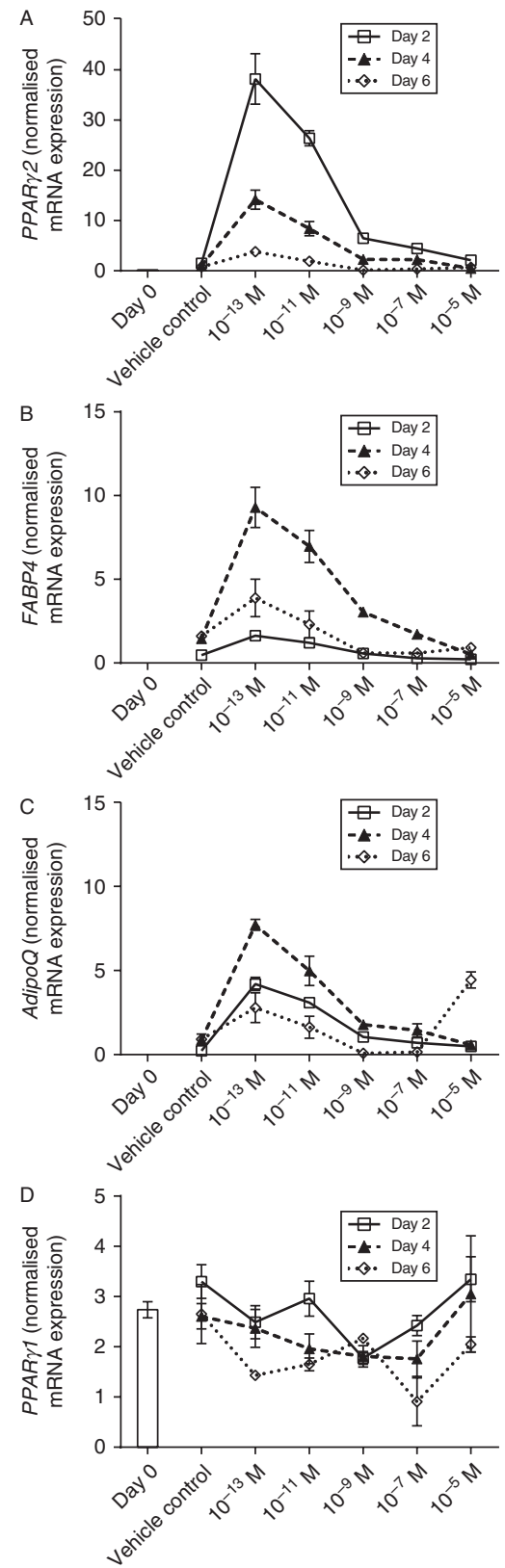

\section{Figure 3}

Dose-dependent effects of $1,25(\mathrm{OH})_{2} \mathrm{D}_{3}$ on expression of white adipocyte marker genes. Expression of white adipocyte marker genes was determined by quantitative RT-PCR analysis. Levels of (A) Ppary2, (B) Fabp4,

(C) Adipoq/adiponectin and (D) Ppary1 mRNAs were quantified in $\mathrm{C} 2 \mathrm{C} 12$ cells cultured in the absence or presence of $10^{-13}, 10^{-11}, 10^{-9}, 10^{-7}$ or $10^{-5} \mathrm{M} 1,25(\mathrm{OH})_{2} \mathrm{D}_{3}$ for 2,4 or 6 days in adipogenic differentiation media. Expression at day 0 (before differentiation media and $1,25(\mathrm{OH})_{2} \mathrm{D}_{3}$ was added) is also included and is indicated by a bar (in some instances, this was very low). Significant two-way interactions between day of differentiation and $1,25(\mathrm{OH})_{2} \mathrm{D}_{3}$ concentration were observed for PPAR $\gamma 2$, FABP4 and AdipoQ $(P<0.001$ for all). For PPAR $\gamma 1$, there was a significant effect of stage of differentiation $(P=0.002)$ and a significant effect of $1,25(\mathrm{OH})_{2} \mathrm{D}_{3}$ concentration $(P=0.005)$, but no interaction. Printed in Great Britain
$1,25(\mathrm{OH})_{2} \mathrm{D}_{3}$ concentration $\times$ day interaction; Fig. 5C). Finally, myf5 mRNA was up-regulated in control cells in adipogenic media at days 2 and 4 (Fig. 5D), but this was inhibited by increasing concentrations of $1,25(\mathrm{OH})_{2} \mathrm{D}_{3}$ in a dose-dependent manner, with $10^{-5} \mathrm{M} 1,25(\mathrm{OH})_{2} \mathrm{D}_{3}$ appearing to block differentiation $(P<0.001$ for $1,25(\mathrm{OH})_{2} \mathrm{D}_{3}$ concentration $\times$ day interaction; Fig. 5D).

In summary, there were only relatively small effects of $1,25(\mathrm{OH})_{2} \mathrm{D}_{3}$ on cells incubated in myogenic media (see Supplementary Figure 1E, F, G and H), mainly due to the effects of the highest (supraphysiological) concentration $\left(10^{-5} \mathrm{M}\right)$. However, supplementation of adipogenic media with physiological $\left(10^{-13}, 10^{-11}\right.$ and $\left.10^{-9} \mathrm{M}\right)$ concentrations of $1,25(\mathrm{OH})_{2} \mathrm{D}_{3}$ increased $\mathrm{CK}, \mathrm{MyoD}$ and myogenin mRNA, suggesting an induction of muscle differentiation. Importantly, $10^{-5} \mathrm{M} \quad 1,25(\mathrm{OH})_{2} \mathrm{D}_{3}$ blocked/inhibited expression of all four myogenic marker genes in adipogenic media, suggesting that this concentration $\left(10^{-5} \mathrm{M}\right)$ may have a different effect to the other concentrations, possibly involving anti-differentiation, pro-apoptotic and/or toxic effects.

\section{Expression of gene markers of brown adipocytes}

As $1,25(\mathrm{OH})_{2} \mathrm{D}_{3}$ was shown to induce gene markers of white adipocytes, we also considered its effect on activation of genes relating to brown adipocytes. Once again, for clarity, only the data from studies in adipogenic media are included, but data for myogenic media are provided in the Supplementary Figure 2A, B, C and D, see section on supplementary data given at the end of this article. Expression of the brown fat-specific marker, uncoupling protein 1 (UCP1), was below detectable levels in cells grown in either myogenic or adipogenic media (data not shown). Likewise, expression of PRD1-BF1-RIZ1 homologous domain containing 16 (Prdm16), previously shown to be required for the transdifferentiation of C2C12 cells to brown adipocytes (Seale et al. 2008), was also below detectable limits (data not shown). However, expression of other brown fat marker genes, Elovl3 and CIDEA, were detectable in cells cultured in adipogenic media, but only after 6 days ( $P<0.001$ for day effect for both genes; Fig. 6A and $B$ respectively). This was preceded by a slight decrease in the expression of CCAAT enhancer binding protein $\beta$ $(C / e b p \beta)$ mRNA $(P<0.001$ for day effect; Fig. 6C) at days 2-6, but no change in expression of PPAR $\gamma$ coactivator $1 \alpha$ (PGC1 $\alpha$; Fig. 6D) mRNA. In contrast to the changes observed in expression of the white adipogenic marker genes, treatment with $1,25(\mathrm{OH})_{2} \mathrm{D}_{3}$ had no significant effect $(P>0.05)$ on expression of any of

Published by Bioscientifica Ltd. 

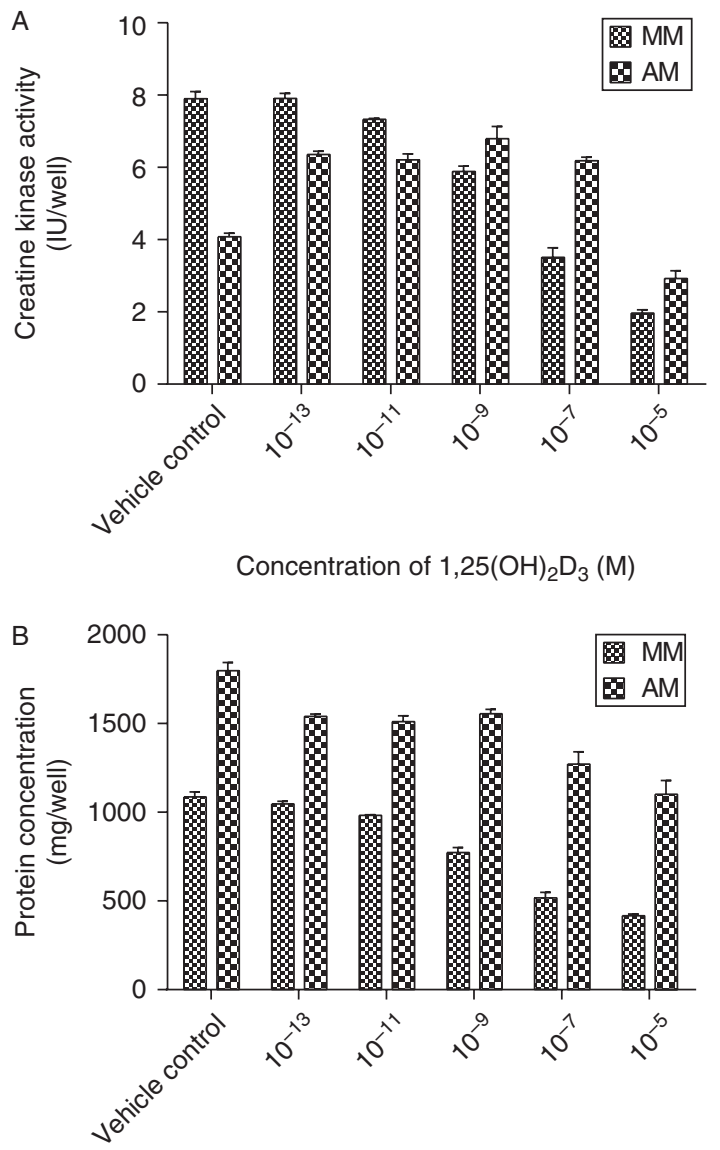

Concentration of $1,25(\mathrm{OH})_{2} \mathrm{D}_{3}(\mathrm{M})$

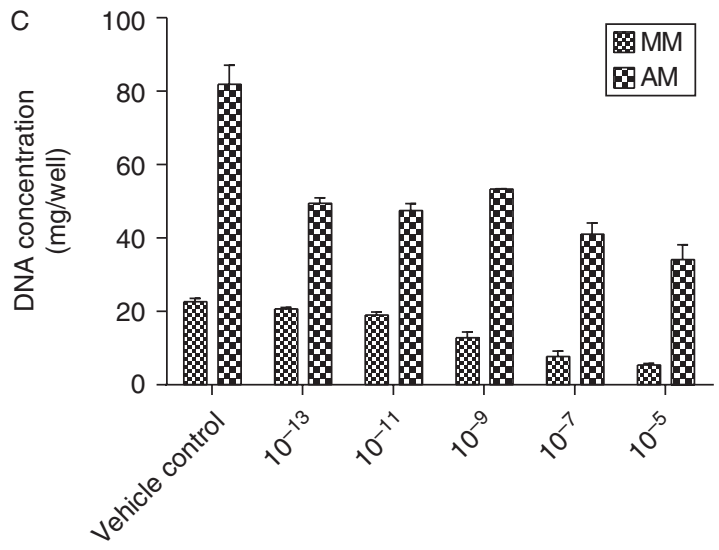

Concentration of $1,25(\mathrm{OH})_{2} \mathrm{D}_{3}(\mathrm{M})$

Figure 4

Dose-dependent effects of $1,25(\mathrm{OH})_{2} \mathrm{D}_{3}$ on (A) CK activity (IU/well), (B) protein ( $\mu \mathrm{g} /$ well) and (C) DNA content ( $\mu \mathrm{g} /$ well) in $\mathrm{C} 2 \mathrm{C} 12$ cells cultured for 4 days in myogenic media (MM) or adipogenic media (AM) with increasing concentrations (vehicle control, $10^{-13}, 10^{-11}, 10^{-9}, 10^{-7}$ and $10^{-5} \mathrm{M}$ ) of $1,25(\mathrm{OH})_{2} \mathrm{D}_{3}$. Significant two-way interactions between media type and $1,25(\mathrm{OH})_{2} \mathrm{D}_{3}$ concentration were observed for CK activity $(P<0.001)$, protein $(P<0.01)$ and DNA $(P<0.001)$ content. Printed in Great Britain the brown adipocyte marker genes, suggesting that $1,25(\mathrm{OH})_{2} \mathrm{D}_{3}$ treatment was not inducing conversion of myoblasts to brown adipocytes, although a longer time frame may be required to be completely sure.

\section{Expression of VDR and the VitD hydroxylating enzymes 1 $\alpha$-hydroxylase and 24-hydroxylase}

As the activity of the VitD system is dependent on the levels of VDR and metabolising enzymes, we also determined their expression in the cell cultures. Once again, for clarity, the data from adipogenic media will mainly be described here, but the data from myogenic media are provided in the Supplementary Figure 2E, F and G. VDR mRNA was expressed in the $\mathrm{C} 2 \mathrm{C} 12$ cells and there was no difference in the level of expression between control cells incubated in either myogenic or adipogenic media (Fig. 7A and Supplementary Figure 2E). In adipogenic media, VDR expression was increased by the highest concentration $\left(10^{-5} \mathrm{M}\right)$ of $1,25(\mathrm{OH})_{2} \mathrm{D}_{3}$ particularly on day $2(P<0.001$ for VitD concentration $\times$ day interaction; Fig. 7A). Basal levels of expression of the $25(\mathrm{OH}) \mathrm{D}_{3}$ activating enzyme, CYP27B1 (1 $\alpha$-hydroxylase) mRNA, increased in control cells incubated in adipogenic media throughout the 6 days of differentiation ( $P<0.001$ for day effect; Fig. 7B), but there was no significant effect of $1,25(\mathrm{OH})_{2} \mathrm{D}_{3}$ on $C Y P 27 B 1$ mRNA expression ( $P>0.05$; Fig. 7B).

In contrast to the activating enzyme, expression of the VitD inactivating enzyme, CYP24a1 (also called 24-hydroxylase), was not detectable in control cells incubated in adipogenic media and did not change with day/stage of differentiation (Fig. 7C), but treatment with

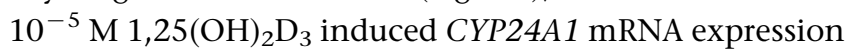
$\left(P<0.001\right.$ for $1,25(\mathrm{OH})_{2} \mathrm{D}_{3}$ concentration effect; Fig. 7C). Hence, the cells appear to be responding to the very high levels of active VitD by increasing the levels of this inactivating enzyme to avoid or minimise potential toxicity effects.

\section{Discussion}

\section{Adipogenic induction}

For the first time, this study shows a bimodal dose-response effect of the active form of $\mathrm{VitD}_{3}$, $1,25(\mathrm{OH})_{2} \mathrm{D}_{3}$, to modulate the capacity of $\mathrm{C} 2 \mathrm{C} 12$ cells to transdifferentiate into adipocytes. The adipogenic potential of $\mathrm{C} 2 \mathrm{C} 12$ cells has been shown previously, with exposure to thiazolidinediones and fatty acids found to induce transdifferentiation to mature adipocytes

Published by Bioscientifica Ltd 

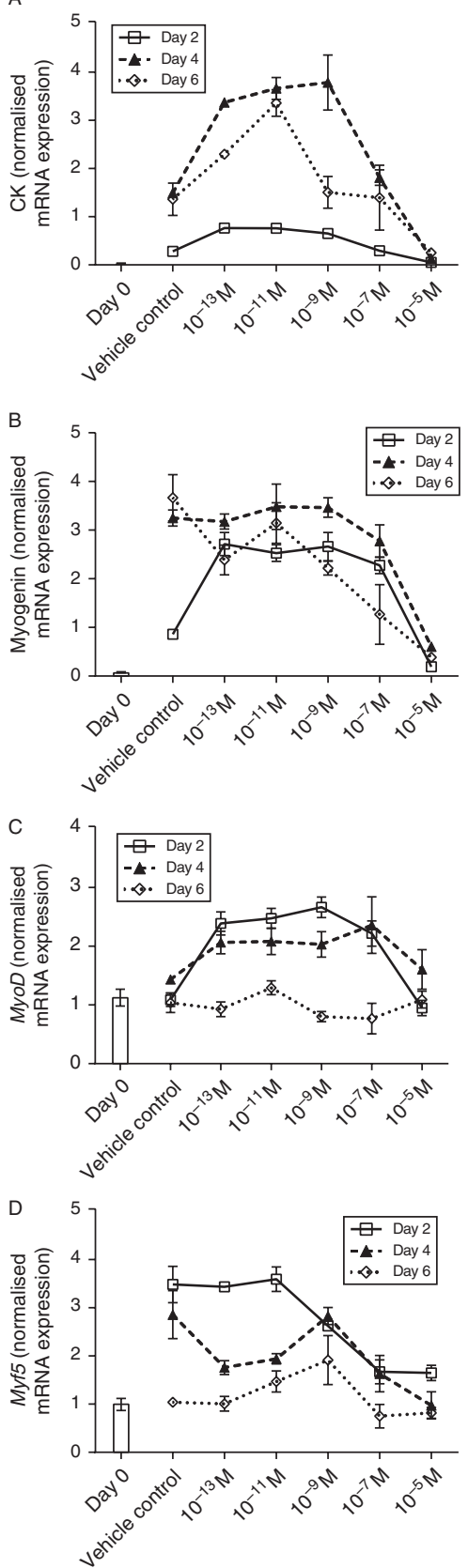

\section{Figure 5}

Dose-dependent effects of $1,25(\mathrm{OH})_{2} \mathrm{D}_{3}$ on expression of skeletal muscle marker genes. Expression of skeletal muscle marker genes was determined by quantitative RT-PCR analysis. Levels of (A) CK, (B) myogenin, (C) MyoD and (D) Myf5 mRNAs were quantified in C2C12 cells cultured in the absence or presence of $10^{-13}, 10^{-11}, 10^{-9}, 10^{-7}$ or $10^{-5} \mathrm{M} 1,25(\mathrm{OH})_{2} \mathrm{D}_{3}$ for 2,4 or 6 days in adipogenic differentiation media. Expression at day 0 (before differentiation media and $1,25(\mathrm{OH})_{2} \mathrm{D}_{3}$ was added) is also included for reference and is indicated by a bar. Significant two-way interactions between day of differentiation and $1,25(\mathrm{OH})_{2} \mathrm{D}_{3}$ concentration were observed for CK, myogenin, Myf5 $(P<0.001$ for all) and $M y o D(P<0.05)$ mRNA transcripts. Printed in Great Britain
(Teboul et al. 1995). A key finding from these studies was that physiologically relevant, sub-nanomolar $\left(10^{-13} \mathrm{M}\right)$ concentrations of $1,25(\mathrm{OH})_{2} \mathrm{D}_{3}$ potently induced accumulation of lipid droplets in adipogenic media. Importantly, this was preceded by a clear up-regulation in expression of the adipogenic marker genes, PPAR $\gamma 2$ and FABP4, which were undetectable in cells grown in myogenic media. PPAR 2 has previously been shown to be pivotal in inducing the transdifferentiation of myogenic precursor cells to the adipogenic lineage ( $\mathrm{Hu}$ et al. 1995, Yu et al. 2006). This study showed that expression of Ppary 2 mRNA peaked on day 2 of differentiation followed by a sequential up-regulation in expression of downstream target genes, Fabp4 and Adipoq, both of which peaked at day 4 in adipogenic media. Interestingly, decreases in lipid accumulation (Oil Red-O percentage area) and adipocyte marker gene expression (Ppary2 and Fabp4) were observed at higher physiological concentrations (between $10^{-13}$ and $10^{-9} \mathrm{M}$ ) of $1,25(\mathrm{OH})_{2} \mathrm{D}_{3}$ without any change in DNA or protein contents, whereas supraphysiological concentrations $\left(10^{-7}\right.$ and $\left.10^{-5} \mathrm{M}\right)$ of $1,25(\mathrm{OH})_{2} \mathrm{D}_{3}$ completely inhibited lipid droplet accumulation and decreased expression of adipogenic marker genes but also reduced DNA and protein contents. Hence, the mechanisms for the anti-differentiation effects of the highest concentrations are potentially due to anti-proliferative and/or pro-apoptotic/toxic effects, but this appears not to be the case for the lower, more physiological concentrations. Therefore, the bimodal effects of $1,25(\mathrm{OH})_{2} \mathrm{D}_{3}$ in altering the transdifferentiation to an adipogenic lineage occurred over a physiologically relevant concentration range and appeared not to be due to anti-proliferative or toxic effects, suggesting that our findings may be indicative of effects in vivo.

Previous studies have reported similar bimodal effects of $1,25(\mathrm{OH})_{2} \mathrm{D}_{3}$ over similar concentration ranges on adipogenesis in 3T3-L1 (Thomson et al. 2007) and Ob17 preadipocytes (Lenoir et al. 1996). Consistent with our findings, Lenoir et al. (1996) showed that $1,25(\mathrm{OH})_{2} \mathrm{D}_{3}$ stimulated adipogenesis at concentrations of $0.25 \mathrm{nM}$ $\left(2.5 \times 10^{-10} \mathrm{M}\right)$ or less, whereas nanomolar concentrations almost completely blocked adipogenic differentiation. Similarly, $0.1 \mathrm{nM}\left(10^{-10} \mathrm{M}\right) 1,25(\mathrm{OH})_{2} \mathrm{D}_{3}$ stimulated adipogenesis, whereas 1 and $10 \mathrm{nM}\left(10^{-9}\right.$ and $10^{-8} \mathrm{M}$ ) inhibited adipogenesis in 3T3-L1 preadipocytes (Thomson et al. 2007). Inhibitory effects of high nanomolar concentrations (1-100 nM or $\left.10^{-9}-10^{-7} \mathrm{M}\right)$ of $1,25(\mathrm{OH})_{2} \mathrm{D}_{3}$ on adipogenesis have also been reported in 3T3-L1 preadipocytes (Blumberg et al. 2006, Kong \& Li

Published by Bioscientifica Ltd 

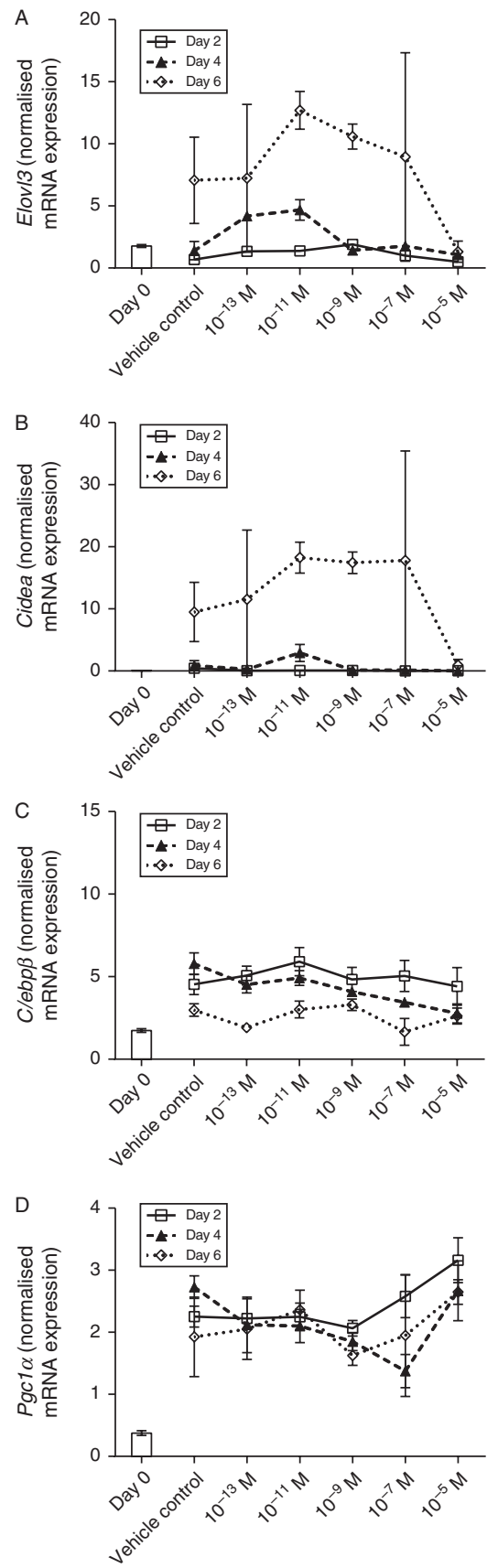

Figure 6

Dose-dependent effects of $1,25(\mathrm{OH})_{2} \mathrm{D}_{3}$ on expression of brown adipocyte marker genes. Expression of brown adipocyte marker genes was determined by quantitative RT-PCR analysis. Levels of (A) Elov/3, (B) Cidea, (C) Clebp $\beta$ and (D) Pgc1 $\alpha$ mRNAs were quantified in C2C12 cells cultured in the absence or presence of $10^{-13}, 10^{-11}, 10^{-9}, 10^{-7}$ or $10^{-5} \mathrm{M} 1,25(\mathrm{OH})_{2} \mathrm{D}_{3}$ for 2, 4 or 6 days in adipogenic differentiation media. Expression at day 0 (before differentiation media and $1,25(\mathrm{OH})_{2} \mathrm{D}_{3}$ was added) is also included for reference and is indicated by a bar. Significant effects of day of differentiation were observed for Elov/3, Cidea and Clebp $\beta$ ( $P<0.001$ for all three), but not PGC1 $\alpha(P>0.05)$. There were no significant effects of $1,25(\mathrm{OH})_{2} \mathrm{D}_{3}$ concentration on any of the brown adipocyte marker genes. Printed in Great Britain
2006, Thomson et al. 2007) and were associated with decreases in C/ebp $\alpha$ and Ppary 2 mRNA expression (Blumberg et al. 2006, Kong \& Li 2006, Thomson et al. 2007). Interestingly, 3T3-L1 preadipocytes were only receptive to this inhibitory effect in the early stages of differentiation (i.e. the induction phase), with no effect observed when $1,25(\mathrm{OH})_{2} \mathrm{D}_{3}$ was administered from $48 \mathrm{~h}$ onwards (Kong \& Li 2006). This receptive period in 3T3-L1 cells may relate to temporal changes in VDR expression, which is rapidly up-regulated in preadipocytes in the first 4-8 h of differentiation and then progressively down-regulated in the following $48 \mathrm{~h}$ (Kong \& Li 2006). We observed something similar, with higher VDR expression at day 2 compared with days 4 and 6 in adipogenic media. Interestingly, only the highest supraphysiological $\left(10^{-5} \mathrm{M}\right)$ concentration of $1,25(\mathrm{OH})_{2} \mathrm{D}_{3}$ increased expression of VDR, particularly at day 2 of differentiation in adipogenic media.

Having established that C2C12 cells appeared to be induced to transdifferentiate into adipocytes, a number of brown fat-specific marker genes were also measured to clarify whether the cells being formed were white or brown adipocytes. Recent findings from lineage tracing studies have shown that brown adipocytes develop in vivo from a MYF5-positive progenitor cell (Seale et al. 2008), suggesting that these myf5-expressing C2C12 cells might also be converting to brown adipocytes. Previous work showed that ectopic overexpression of PRDM16 in C2C12 cells induced Myf5 gene expression and this was associated with diversion of these cells to the brown fat lineage (Seale et al. 2008). In this study, Myf5 mRNA expression in C2C12 cells was up-regulated in adipogenic media compared with myogenic media at all timepoints over the 6-day culture period, but Prdm16 mRNA was expressed at very low levels in all cultures, below the threshold at which expression could be accurately quantified (data not shown). Similarly, Ucp1 expression was not detectable in these cultures (data not shown). Other brown adipocyte-specific marker genes, Elovl3 and Cidea, were activated in cells cultured in adipogenic media, but not until day 6 of differentiation, and the expression was a lot more variable, as indicated by the larger error bars. This suggests that activation of brown adipogenic genes may be occurring, but at a much later stage in the developmental process, for which further investigation is required. However, the absence of any effect of $1,25(\mathrm{OH})_{2} \mathrm{D}_{3}$ treatment on any of the brown fat genes measured suggests that the dose-dependent changes in lipid accumulation observed relate to white rather than brown adipogenesis.

Published by Bioscientifica Ltd. 

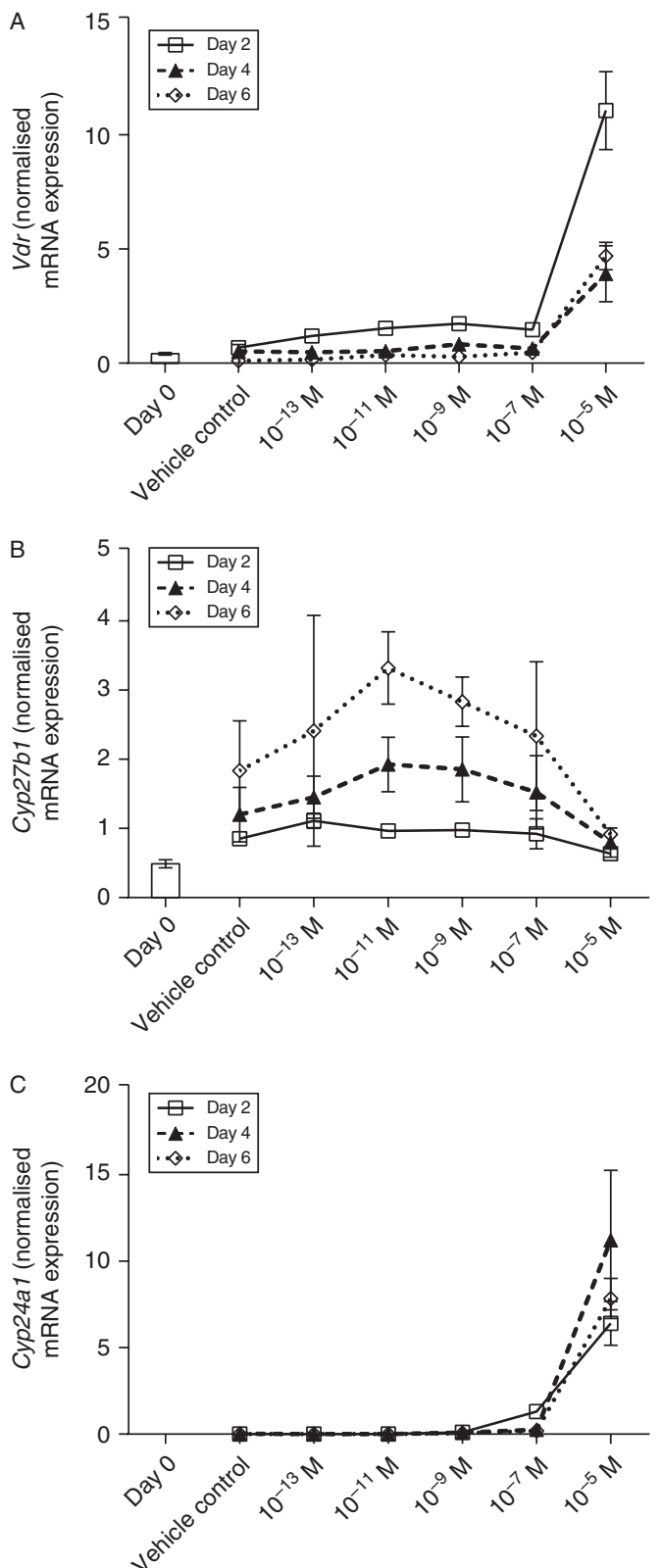

Figure 7

Dose-dependent effects of $1,25(\mathrm{OH})_{2} \mathrm{D}_{3}$ on expression of VDR, CYP27B1 (1 1 -hydroxylase) and CYP24A1 (24-hydroxylase) enzymes. Expression of VitD-related genes was determined by quantitative RT-PCR analysis. Levels of (A) Vdr, (B) Cyp27b1 and (C) Cyp24a1 mRNAs were quantified in C2C12 cells cultured in the absence or presence of $10^{-13}, 10^{-11}, 10^{-9}, 10^{-7}$ or $10^{-5} \mathrm{M} 1,25(\mathrm{OH})_{2} \mathrm{D}_{3}$ for 2,4 or 6 days in adipogenic differentiation media. Expression at day 0 (before differentiation media and $1,25(\mathrm{OH})_{2} \mathrm{D}_{3}$ was added) is also included for reference and is indicated by a bar. A significant two-way interaction $(P<0.001)$ between day of differentiation and $1,25(\mathrm{OH})_{2} \mathrm{D}_{3}$ concentration was observed for VDR only. There was a significant effect of day of differentiation $(P=0.001)$ on expression of Cyp27b1 mRNA, but no effect of $1,25(\mathrm{OH})_{2} \mathrm{D}_{3}$ concentration. By contrast, there was a significant effect $(P<0.001)$ of $1,25(\mathrm{OH})_{2} \mathrm{D}_{3}$ concentration on Cyp24a1 mRNA, but no effect of day of differentiation. Printed in Great Britain

\section{Myogenic differentiation}

Our results show that exposure to adipogenic media induces $\mathrm{C} 2 \mathrm{C} 12$ cells to transdifferentiate into cells that accumulate lipid droplets and thus resemble a mature adipocyte. This indicates some degree of plasticity in the lineage potential of this 'muscle cell line', but it should be noted that extensive myotube formation was still evident, even in the presence of adipogenic media. Previous studies whereby C2C12 cells were induced to form adipocytes following exposure to thiazolidinediones and fatty acids indicated that this transdifferentiation to mature adipocytes was associated with an inhibition of myogenic differentiation (Teboul et al. 1995). An initial myogenesis inhibitory effect of exposing $\mathrm{C} 2 \mathrm{C} 12$ cells to adipogenic media was evident in our studies, as CK activity was reduced in control cells exposed to adipogenic compared with myogenic media. This was associated with delayed activation of myogenesis, as indicated by reduced myogenin and $C k$ mRNA at day 2 and was possibly a consequence of increased cell proliferation, as indicated by the increase in DNA content observed, presumably due to the higher FBS content of the adipogenic media. However, this study indicated that the three physiological concentrations $\left(10^{-13}-10^{-9} \mathrm{M}\right)$ of $1,25(\mathrm{OH})_{2} \mathrm{D}_{3}$ appeared to induce myogenesis (in adipogenic media only), rather than inhibit it. Indeed, the low physiological $\left(10^{-13} \mathrm{M}\right)$ concentration of $1,25(\mathrm{OH})_{2} \mathrm{D}_{3}$ appeared to increase both adipogenesis and myogenesis, whereas the high physiological $\left(10^{-9} \mathrm{M}\right)$ concentration only increased myogenesis and the highest supraphysiological $\left(10^{-5} \mathrm{M}\right)$ concentration inhibited both. This is consistent with previous work in which a high physiological concentration $\left(10^{-9} \mathrm{M}\right)$ of $1,25(\mathrm{OH})_{2} \mathrm{D}_{3}$ was shown to increase fusion/ differentiation of chick embryo myoblasts during late stages of myogenesis (Capiati et al. 1999).

\section{Local regulation of activity}

Circulating levels of $1,25(\mathrm{OH})_{2} \mathrm{D}_{3}$ are tightly regulated by the activity of the hydroxylating enzymes, $1 \alpha$-hydroxylase (CYP27b1) and 24-hydroxylase (CYP24a1). In this study, the activating enzyme, Cyp27b1 mRNA, was found to be expressed by $\mathrm{C} 2 \mathrm{C} 12$ cells and expression increased with day/stage of differentiation in adipogenic media, but there was no effect of $1,25(\mathrm{OH})_{2} \mathrm{D}_{3}$. Although the highest concentration $\left(10^{-5} \mathrm{M}\right)$ appeared to reduce expression of Cyp27b1 mRNA, this was not statistically significant. Previous work (Turunen et al. 2007) has shown that $1,25(\mathrm{OH})_{2} \mathrm{D}_{3}$ administered at suprananomolar levels

Published by Bioscientifica Ltd 
$\left(10^{-8} \mathrm{M}\right)$ suppressed $1 \alpha$-hydroxylase (CYP27b1) promoter activity in HEK 293 cells. It should be noted that there was no detectable expression in the $\mathrm{C} 2 \mathrm{C} 12$ cells of the inactivating enzyme, CYP24a1 (24-hydroxylase), apart from when $1,25(\mathrm{OH})_{2} \mathrm{D}_{3}$ was supplemented at levels in excess of the physiological range $\left(10^{-7}-10^{-5} \mathrm{M}\right)$, when an induction was observed. This likely occurs as a mechanism to protect the cells from toxic effects of such high non-physiological levels of the active vitamin. Similarly, VDR mRNA was very low (but detectable) and induced at the highest $\left(10^{-5} \mathrm{M}\right)$ concentration. This would appear to suggest that there were toxic effects of the highest concentration(s) of $1,25(\mathrm{OH})_{2} \mathrm{D}_{3}$, but that this was not the case for the other, more physiological concentrations $\left(10^{-13}-10^{-9} \mathrm{M}\right)$, indicating that their effects on morphology and gene expression are unlikely to be via anti-proliferative/pro-apoptotic mechanisms.

\section{Physiological relevance}

It is difficult to extrapolate from this study to the likely effects of VitD deficiency on the level of transdifferentiation of muscle precursor cells to adipocytes that occur in muscle in vivo. Our findings suggest that low (deficient) levels (Zittermann et al. 2009) of $1,25(\mathrm{OH})_{2} \mathrm{D}_{3}$ (i.e. $10^{-13} \mathrm{M}$ ) may actually enhance adipogenic transdifferentiation, whereas high (sufficient) levels (i.e. $10^{-9} \mathrm{M}$ ) inhibit adipogenesis, thereby potentially impacting on fat infiltration and muscle function. A number of studies have demonstrated the ability of primary muscle cells to form adipocytes, but the mechanisms involved are not clear (Asakura et al. 2001, Csete et al. 2001, Aguiari et al. 2008). However, the C2C12 cell model is likely to be a conservative model of adipogenic transdifferentiation, as primary satellite cells isolated from pig muscle demonstrate a much higher degree of plasticity with a greater number of adipocytes and a lower number of myotubes formed in response to adipogenic media (Redshaw et al. 2010). The exposure of myogenic precursor cells to adipogenic regulatory factors may be an important factor in contributing to the increased fat infiltration seen in muscle, for example during ageing and VitD deficiency, although infiltration by already committed adipocyte populations is also possible. VitD has been shown to play a key regulatory role in myogenesis and is likely to be important in muscle fibre repair (Capiati et al. 1999, Garcia et al. 2011).

A speculative interpretation of the bimodal response of $\mathrm{C} 2 \mathrm{C} 12$ cells to $1,25(\mathrm{OH})_{2} \mathrm{D}_{3}$ observed in vitro is that it represents an energy-conserving mechanism in vivo that has evolved in response to the changing seasons and enables extra energy to be repartitioned into fat depots. Certainly for our ancestors, a significant quantity of VitD was primarily obtained from exposure to u.v./sunlight, which induces the conversion of 7-dehydrocholesterol to $\mathrm{VitD}_{3}$. Low levels of VitD in the body, which possibly occur during periods of low u.v. exposure such as winter (Moosgaard et al. 2005, Aguiari et al. 2008), may act as an important regulatory cue in inducing muscle precursor cells to form adipocytes rather than myofibres and enable extra fat depots to be stored in the body during periods of austerity. This speculative hypothesis needs testing in an appropriate animal model.

In conclusion, this is the first study to show that low physiological concentrations $(0.1-10 \mathrm{pM}$ or $\left.10^{-13}-10^{-11} \mathrm{M}\right)$ of $1,25(\mathrm{OH})_{2} \mathrm{D}_{3}$, which may represent a VitD-deficient state, induce myoblasts to transdifferentiate into the adipogenic lineage and appears to involve activation of PPAR $\gamma 2$. These findings have implications for muscle health and function as well as whole-body energy metabolism because an increase in fat infiltration within skeletal muscle has been linked with a decrease in functional strength and impairment of glucose tolerance, leading to an increased susceptibility to obesity and type II diabetes (Goodpaster et al. 2003, Hilton et al. 2008). High concentrations ( $1 \mathrm{nM}$ or $10^{-9} \mathrm{M}$ and above) of $1,25(\mathrm{OH})_{2} \mathrm{D}_{3}$ appeared to block adipogenic transdifferentiation, suggesting that changes in physiological concentrations of $1,25(\mathrm{OH})_{2} \mathrm{D}_{3}$ have a major impact on the determination of cell fate of myogenic precursor cells. Furthermore, our data indicate that levels of $1,25(\mathrm{OH})_{2} \mathrm{D}_{3}$ in the serum and muscle are likely to be important biomarkers linking VitD intakes and optimal muscular health. Given the widespread prevalence of VitD deficiency, particularly in the elderly population, understanding the role of this vitamin in muscle differentiation processes throughout life will be key to defining nutritional parameters for maintaining life-long health and well-being.

Supplementary data

This is linked to the online version of the paper at http://dx.doi.org/10.1677/ JOE-12-0234.

\section{Declaration of interest}

The authors declare that there is no conflict of interest that could be perceived as prejudicing the impartiality of the research reported.

Published by Bioscientifica Ltd. 


\section{Funding}

This research was supported by funding from the University of Nottingham and a Wellcome Trust Value in People Award to K J P R.

\section{References}

Aguiari P, Leo S, Zavan B, Vindigni V, Rimessi A, Bianchi K, Franzin C, Cortivo R, Rossato M, Vettor R et al. 2008 High glucose induces adipogenic differentiation of muscle-derived stem cells. PNAS $\mathbf{1 0 5}$ 1226-1231. (doi:10.1073/pnas.0711402105)

Asakura A, Komaki M \& Rudnicki M 2001 Muscle satellite cells are multipotential stem cells that exhibit myogenic, osteogenic, and adipogenic differentiation. Differentiation 68 245-253. (doi:10.1046/j. 1432-0436.2001.680412.x)

Bischoff HA, Stahelin HB, Dick W, Akos R, Knecht M, Salis C, Nebiker M, Theiler R, Pfeifer M, Begerow B et al. 2003 Effects of vitamin D and calcium supplementation on falls: a randomized controlled trial. Journal of Bone and Mineral Research 18 343-351. (doi:10.1359/jbmr. 2003.18.2.343)

Blumberg JM, Tzameli I, Astapova I, Lam FS, Flier JS \& Hollenberg AN 2006 Complex role of the vitamin $\mathrm{D}$ receptor and its ligand in adipogenesis in 3T3-L1 cells. Journal of Biological Chemistry 281 11205-11213. (doi:10.1074/jbc.M510343200)

Brown DM, Parr T \& Brameld JM 2012 Myosin heavy chain mRNA isoforms are expressed in two distinct cohorts during C2C12 myogenesis. Journal of Muscle Research and Cell Motility 32 383-390. (doi:10.1007/ s10974-011-9267-4)

Capiati DA, Tellez-Inon MT \& Boland RL 1999 Participation of protein kinase $\mathrm{C} \alpha$ in 1,25-dihydroxy-vitamin D3 regulation of chick myoblast proliferation and differentiation. Molecular and Cellular Endocrinology 153 39-45. (doi:10.1016/S0303-7207(99)00093-3)

Ceglia L 2008 Vitamin D and skeletal muscle tissue and function. Molecular Aspects of Medicine 29 407-414. (doi:10.1016/j.mam.2008.07.002)

Csete M, Walikonis J, Slawny N, Wei Y, Korsnes S, Doyle JC \& Wold B 2001 Oxygen-mediated regulation of skeletal muscle satellite cell proliferation and adipogenesis in culture. Journal of Cellular Physiology 189 189-196. (doi:10.1002/jcp.10016)

Drittanti L, de Boland AR \& Boland R 1989 Modulation of DNA synthesis in cultured muscle cells by 1,25-dihydroxyvitamin D-3. Biochimica et Biophysica Acta 1014 112-119. (doi:10.1016/0167-4889(89)90022-0)

Garcia LA, King KK, Ferrini MG, Norris KC \& Artaza JN 2011 1,25(OH)2 vitamin D3 stimulates myogenic differentiation by inhibiting cell proliferation and modulating the expression of promyogenic growth factors and myostatin in C2C12 skeletal muscle cells. Endocrinology 152 2976-2986. (doi:10.1210/en.2011-0159)

Goodpaster BH, Carlson CL, Visser M, Kelley DE, Scherzinger A, Harris TB, Stamm E \& Newman AB 2001 Attenuation of skeletal muscle and strength in the elderly: The Health ABC Study. Journal of Applied Physiology 90 2157-2165.

Goodpaster BH, Krishnaswami S, Resnick H, Kelley DE, Haggerty C, Harris TB, Schwartz AV, Kritchevsky S \& Newman AB 2003 Association between regional adipose tissue distribution and both type 2 diabetes and impaired glucose tolerance in elderly men and women. Diabetes Care 26 372-379. (doi:10.2337/diacare.26.2.372)

Grimaldi PA, Teboul L, Inadera H, Gaillard D \& Amri EZ 1997 Trans-differentiation of myoblasts to adipoblasts: triggering effects of fatty acids and thiazolidinediones. Prostaglandins, Leukotrienes, and Essential Fatty Acids 57 71-75. (doi:10.1016/S0952-3278(97)90495-6)

Harwood RH, Sahota O, Gaynor K, Masud T \& Hosking DJ 2004 A randomised, controlled comparison of different calcium and vitamin $\mathrm{D}$ supplementation regimens in elderly women after hip fracture: The Nottingham Neck of Femur (NONOF) Study. Age and Ageing 33 45-51. (doi:10.1093/ageing/afh002)
Hemmings KM, Parr T, Daniel ZC, Picard B, Buttery PJ \& Brameld JM 2009 Examination of myosin heavy chain isoform expression in ovine skeletal muscles. Journal of Animal Science 87 3915-3922. (doi:10.2527/ jas.2009-2067)

Hilton TN, Tuttle LJ, Bohnert KL, Mueller MJ \& Sinacore DR 2008 Excessive adipose tissue infiltration in skeletal muscle in individuals with obesity, diabetes mellitus, and peripheral neuropathy: association with performance and function. Physical Therapy 88 1336-1344. (doi:10.2522/ ptj.20080079)

Holick MF 2007 Vitamin D deficiency. New England Journal of Medicine 357 266-281. (doi:10.1056/NEJMra070553)

Holst D, Luquet S, Kristiansen K \& Grimaldi PA 2003 Roles of peroxisome proliferator-activated receptors $\delta$ and $\gamma$ in myoblast transdifferentiation. Experimental Cell Research 288 168-176. (doi:10.1016/S00144827(03)00179-4)

Hu E, Tontonoz P \& Spiegelman BM 1995 Transdifferentiation of myoblasts by the adipogenic transcription factors PPAR $\gamma$ and C/EBP $\alpha$. PNAS 92 9856-9860. (doi:10.1073/pnas.92.21.9856)

Hurley MS, Flux C, Salter AM \& Brameld JM 2006 Effects of fatty acids on skeletal muscle cell differentiation in vitro. British Journal of Nutrition 95 623-630. (doi:10.1079/BJN20051711)

Ishida Y, Taniguchi H \& Baba S 1988 Possible involvement of $1 \alpha, 25$-dihydroxyvitamin D3 in proliferation and differentiation of 3T3-L1 cells. Biochemical and Biophysical Research Communications 151 1122-1127. (doi:10.1016/S0006-291X(88)80482-0)

Kajimura S, Seale P, Kubota K, Lunsford E, Frangioni JV, Gygi SP \& Spiegelman BM 2009 Initiation of myoblast to brown fat switch by a PRDM16-C/EBP- $\beta$ transcriptional complex. Nature 460 1154-1158. (doi:10.1038/nature08262)

Kong J \& Li YC 2006 Molecular mechanism of 1,25-dihydroxyvitamin D3 inhibition of adipogenesis in 3T3-L1 cells. American Journal of Physiology. Endocrinology and Metabolism 290 E916-E924. (doi:10.1152/ ajpendo.00410.2005)

Lenoir C, Dace A, Martin C, Bonne J, Teboul M, Planells R \& Torresani J 1996 Calcitriol down-modulates the 3,5,3' triiodothyronine $\left(T_{3}\right)$ receptors and affects, in a biphasic manner, the $\mathrm{T}_{3}$-dependent adipose differentiation of Ob 17 preadipocytes. Endocrinology 137 4268-4276. (doi:10.1210/en.137.10.4268)

Lowry OH, Rosebrough NJ, Farr AL \& Randall RJ 1951 Protein measurement with the Folin phenol reagent. Journal of Biological Chemistry 193 265-275.

McLeod JF \& Cooke NE 1989 The vitamin D-binding protein $\alpha$-fetoprotein, albumin multigene family: detection of transcripts in multiple tissues. Journal of Biological Chemistry 264 21760-21769.

Moosgaard B, Vestergaard P, Heickendorff L, Melsen F, Christiansen P \& Mosekilde L 2005 Vitamin D status, seasonal variations, parathyroid adenoma weight and bone mineral density in primary hyperparathyroidism. Clinical Endocrinology 63 506-513. (doi:10.1111/j.1365-2265. 2005.02371.x)

Moreira-Pfrimer LD, Pedrosa MA, Teixeira L \& Lazaretti-Castro M 2009 Treatment of vitamin D deficiency increases lower limb muscle strength in institutionalized older people independently of regular physical activity: a randomized double-blind controlled trial. Annals of Nutrition and Metabolism 54 291-300. (doi:10.1159/000235874)

Oh JH, Kim SH, Kim JH, Shin YH, Yoon JP \& Oh CH 2009 The level of vitamin $\mathrm{D}$ in the serum correlates with fatty degeneration of the muscles of the rotator cuff. Journal of Bone and Joint Surgery. British Volume 91 1587-1593. (doi:10.1302/0301-620X.91B12.22481)

Rago R, Mitchen J \& Wilding G 1990 DNA fluorometric assay in 96-well tissue culture plates using Hoechst 33258 after cell lysis by freezing in distilled water. Analytical Biochemistry 191 31-34. (doi:10.1016/00032697(90)90382-J)

Redshaw Z, McOrist S \& Loughna P 2010 Muscle origin of porcine satellite cells affects in vitro differentiation potential. Cell Biochemistry and Function 28 403-411. (doi:10.1002/cbf.1670) 
Ryall JG, Schertzer JD \& Lynch GS 2008 Cellular and molecular mechanisms underlying age-related skeletal muscle wasting and weakness. Biogerontology 9 213-228. (doi:10.1007/s10522-008-9131-0)

Sato M \& Hiragun A 1988 Demonstration of 1 $\alpha, 25$-dihydroxyvitamin D3 receptor-like molecule in ST 13 and 3T3 L1 preadipocytes and its inhibitory effects on preadipocyte differentiation. Journal of Cellular Physiology 135 545-550. (doi:10.1002/jcp.1041350326)

Sato Y, Iwamoto J, Kanoko T \& Satoh K 2005 Low-dose vitamin D prevents muscular atrophy and reduces falls and hip fractures in women after stroke: a randomized controlled trial. Cerebrovascular Diseases 20 187-192. (doi:10.1159/000087203)

Seale P, Bjork B, Yang W, Kajimura S, Chin S, Kuang S, Scime A, Devarakonda S, Conroe HM, Erdjument-Bromage H et al. 2008 PRDM16 controls a brown fat/skeletal muscle switch. Nature 454 961-967. (doi:10.1038/nature07182)

Tagliafico AS, Ameri P, Bovio M, Puntoni M, Capaccio E, Murialdo G \& Martinoli C 2010 Relationship between fatty degeneration of thigh muscles and vitamin D status in the elderly: a preliminary MRI study. AJR. American Journal of Roentgenology 194 728-734. (doi:10.2214/AJR. 09.3130)

Takeyama K \& Kato S 2011 The vitamin D3 1 $\alpha$-hydroxylase gene and its regulation by active vitamin D3. Bioscience, Biotechnology, and Biochemistry 75 208-213. (doi:10.1271/bbb.100684)

Teboul L, Gaillard D, Staccini L, Inadera H, Amri EZ \& Grimaldi PA 1995 Thiazolidinediones and fatty acids convert myogenic cells into adipose-like cells. Journal of Biological Chemistry 270 28183-28187. (doi:10.1074/jbc.270.47.28183)

Thomson B, Ahrens JM, Ntambi JM, DeLuca HF \& Clagett-Dame M 2007 2-Methylene-19-nor-1 $\alpha$-hydroxyvitamin D3 analogs inhibit adipocyte differentiation and PPAR $\gamma 2$ gene transcription. Archives of Biochemistry and Biophysics 460 192-201. (doi:10.1016/j.abb.2006.12.020)

Tonge DP, Jones SW, Bardsley RG \& Parr T 2010 Characterisation of the sarcomeric myosin heavy chain multigene family in the laboratory guinea pig. BMC Molecular Biology 11 52. (doi:10.1186/14712199-11-52)

Turunen MM, Dunlop TW, Carlberg C \& Vaisanen S 2007 Selective use of multiple vitamin D response elements underlies the $1 \alpha, 25$-dihydroxyvitamin D3-mediated negative regulation of the human CYP27B1 gene. Nucleic Acids Research 35 2734-2747. (doi:10.1093/nar/gkm179)

Vettor R, Milan G, Franzin C, Sanna M, De Coppi P, Rizzuto R \& Federspil G 2009 The origin of intermuscular adipose tissue and its pathophysiological implications. American Journal of Physiology. Endocrinology and Metabolism 297 E987-E998. (doi:10.1152/ajpendo. 00229.2009)

Yoshikawa S, Nakamura T, Tanabe H \& Imamura T 1979 Osteomalacic myopathy. Endocrinologia Japonica 26 65-72. (doi:10.1507/ endocrj1954.26.Supplement_65)

Yu YH, Liu BH, Mersmann HJ \& Ding ST 2006 Porcine peroxisome proliferator-activated receptor $\gamma$ induces transdifferentiation of myocytes into adipocytes. Journal of Animal Science 84 2655-2665. (doi:10.2527/jas.2005-645)

Zhuang H, Lin Y \& Yang G 2007 Effects of 1,25-dihydroxyvitamin D3 on proliferation and differentiation of porcine preadipocyte in vitro. Chemico-Biological Interactions 170 114-123. (doi:10.1016/j.cbi.2007. 07.012)

Zittermann A, Schleithoff SS, Frisch S, Gotting C, Kuhn J, Koertke H, Kleesiek K, Tenderich G \& Koerfer R 2009 Circulating calcitriol concentrations and total mortality. Clinical Chemistry 55 1163-1170. (doi:10.1373/clinchem.2008.120006)

Zoico E, Rossi A, Di Francesco V, Sepe A, Olioso D, Pizzini F, Fantin F, Bosello O, Cominacini L, Harris TB et al. 2010 Adipose tissue infiltration in skeletal muscle of healthy elderly men: relationships with body composition, insulin resistance, and inflammation at the systemic and tissue level. Journals of Gerontology. Series A, Biological Sciences and Medical Sciences 65 295-299. (doi:10.1093/gerona/glp155)

Received in final form 17 December 2012

Accepted 17 January 2013

Accepted Preprint published online 17 January 2013
C 2013 Society for Endocrinology Printed in Great Britain
Published by Bioscientifica Ltd. 